\title{
Stem anatomy in the spiny american palm Bactris (Arecaceae-Bactridinae)
}

\author{
Tracy Monique Magellan ${ }^{1,4}$, P. Barry Tomlinson² and Brett A. Huggett ${ }^{3}$
}

Received: 11.02.2015; accepted: 07.05.2015

\begin{abstract}
Stem anatomy in the spiny american palm Bactris (Arecaceae-Bactridinae)). Bactris trunks are made entirely by long sustained primary growth so that mechanical properties develop progressively as the trunk matures. Anatomical features vary throughout the stem so that one small sample is a limited representation. This limits the use for stem histology with systematic purposes. We examined stem anatomy in 17 out of 73 species representing all major sub-generic groups. Stem features do not associate well with the subdivision of the genus. Distinctive structural and developmental features: are the presence of fiber strands independent of the vascular tissues, the modified ground parenchyma with a late formation of air-lacunae, and the early inception of the mechanically significant outer central cylinder. Cell expansion and fiber wall thickening develop as the stem ages, but vary in their expression in stems of different diameter. Our example thus provides an explanation for the difficulty of identifying the systematic position of fossil palm stems.
\end{abstract}

Keywords: biomechanics, fiber development, primary growth, stem anatomy

RESUMO - (Anatomia de caule na palmeira espinhosa americana Bactris (Arecaceae-Bactridinae)). Os caules de Bactris são totalmente construídos por um longo e contínuo crescimento primário, de tal modo que as propriedades mecânicas se desenvolvem de maneira progressiva enquanto o caule amadurece. Os aspectos anatômicos variam ao longo do caule, e por isso uma amostra pequena acaba sendo uma representação limitada. Isso restringe o uso da histologia dos caules com objetivos sistemáticos. Nós examinamos a anatomia do caule em 17 das 73 espécies, representantes dos principais grupos subgenéricos. As características do caule não são associadas adequadamente com a subdivisão do gênero. As características estruturais e de desenvolvimento peculiares são: a presença de cordões de fibras independentes dos tecidos vasculares, parênquima fundamental modificado com uma formação tardia dos espaços de ar (lacunas), e o início precoce do cilindro central exterior mecanicamente significativo. A expansão celular e o espessamento da parede da fibra se desenvolvem com a idade dos caules, mas variam na maneira que eles se apresentam nos caules de diâmetros diferentes. Nosso exemplo então fornece uma explanação para a dificuldade na identificação da posição sistemática dos caules fósseis de palmeiras.

Palavras-chave: anatomia do caule, biomecânica, crescimento primário, desenvolvimento da fibra

\section{Introduction}

Palms (Arecaceae/Palmae) might be described as "familiar strangers." They are familiar tropical icons and there is extensive knowledge of much of their biology (e.g. Dransfield et al. 2008), but they are incompletely known at the structural level. Lamina histology is best understood (e.g. Horn et al. 2009) especially in relation to a robust phylogeny (Baker et al. 2009), which has been used to demonstrate considerable homoplasy (Tomlinson et al. 2011). However, much less information is available concerning stem anatomy in a comparative context, reflecting limited availability of stem material by destructive sampling, the technical difficulty of preparing sections for anatomical study using standard histological techniques and the inherent variability of stem tissues within a single trunk (Tomlinson \& Hugget 2012). As a consequence of these difficulties the identity of fossil palms in terms of extant species is rendered difficult. An overview of this problem is provided in Thomas (2011) and Thomas and De Franceschi (2013) with some suggestions for a

1. Montgomery Botanical Center, 11901 Old Cutler Rd, Coral Gables, FL 33156, U.S.A

2. The Kampong of the National Tropical Botanical Garden, 4013 Douglas Rd, Miami, FL 33133, USA

3. Harvard University, Department of Organismic and Evolutionary Biology, 16 Divinity Avenue, Cambridge, MA 02138, USA

4. Corresponding author: tracym@montgomerybotanical.org 
resolution. However, our limited knowledge of the systematic usefulness of anatomical characters in the stem of existing palms hinders any understanding of the changes that may have occurred in stem histology as palms evolved. Here we demonstrate how these shortcomings can be addressed within a single genus for which we have a reasonably large sampling, using as models an existing typology (Henderson 2000) and a recent molecular phylogeny (Eiserhardt 2011).

We approach this problem by considering stem anatomical features in the genus Bactris Jacq. ex Scop. based on a fairly comprehensive sampling of different species. A useful adjunct has been the availability of sections at different heights within a single stem, which gives some indication of changes in histology as the stem ages. These changes are the result of sustained primary growth, an inherent feature of palm stem development, so that it can be claimed that palms are the longest-lived trees (Tomlinson \& Huggett 2012).

According to the recent monograph of Henderson (2000), Bactris includes 73 species, which are divided into six informal groups, as in table 1, and we have studied material representing all of these groups so that our survey is complete in that respect. Our material includes some 40 samples from 17 named and several unnamed species collected over an extended period beginning in the 1960s. Our results indicate to some extent what features are diagnostic for the genus, how they vary in different groups, and at different stages of development. Features also vary according to differences in stem diameter. As explained by Henderson (2000), Bactris is a notoriously difficult genus to study because most species are spiny on all parts, including even flowers and fruits, so they tend to be avoided by all but the most committed collectors. For this reason species are rarely cultivated (figure $1 \mathrm{a}, \mathrm{b})$. The most conspicuous exception is $B$. gasipaes (Pejibaye), a species with several spineless varieties not known in the wild, but widely cultivated for its fruit, which have a rich fleshy mesocarp, and for palm hearts.

In Bactris there are numerous nomenclatural problems conditioned in part by destruction of many types and the fragmentary nature of many herbarium specimens, resulting in an extensive synonymy. The applicability of Henderson's grouping has been tested in a molecular systematic survey (Eiserhardt et al. 2011), but without their complete acceptance. An earlier cladistic study by Sanders (1991) provided a wealth of diagnostic information and a critique of earlier systematic work. However, the existence of Henderson's timely monograph provides a typological background and the inspiration for our own limited study. The genus Bactris and the subtribe Bactridinae to which it belongs are clearly monophyletic (Dransfied et al. 2008, Eiserhardt 2011), a conclusion with which our own observations are not in conflict.

The genus Bactris has a wide distribution in the New World, from the Caribbean, e.g., three species in Jamaica according to Salzman \& Judd (1995), to Central America (De Nevers et al. 1996), but most abundant in tropical South America (Dransfield et al. 2008). It consists of mostly small to moderately-sized plants, almost all of which are multiple-stemmed, i.e. arising from a sympodially-branched but congested rhizome system. Stem size varies over almost two orders of magnitude, from as narrow as $5 \mathrm{~mm}$ diameter (e.g. B. simplicifrons) to $25 \mathrm{~cm}$ (as in the Guilielma group). Figure 1 indicates the rate of development of a mid-sized species, the widespread B. major, $17 \mathrm{yr}$ old with about 10 stems (figure 1 a) and a 50 yr old specimen (figure $1 \mathrm{~b}$ ) with about 35 stems up to a maximum height of about $6 \mathrm{~m}$.

Our survey is conditioned by the limited material available, but it is still more complete than any prior survey. Palm stems are technically difficult to work on and have extended developmental processes, which complicates their comparative study. Consequently our paper provides a sign-post for any student of palm anatomy and particularly for the paleobotanists confronted with systematic identification of fossil palms. The identification problem is not wholly unsurmountable as indicated by Thomas (2011) and Thomas and De Franceschi (2013), who produced results of value at higher taxonomic levels.

\section{Material and methods}

Accumulated collections of permanent slides made from various stems, beginning in the 1960s, were used in our study. Work was done initially at two institutions; Fairchild Tropical Botanic Garden, 10901 Old Cutler Rd, Coral Gables, FL 33156, and Harvard Forest, Harvard University, Petersham, MA 01366. We examined stem anatomy in 17 out of 73 species representing all major sub-generic groups. Original sources are listed in table 1 . These were (i) collections made by one of us (PBT) of fluid fixed-material from Trinidad and Costa Rica, together with the living collections of FTBG and Montgomery Botanical Center (figure 1 b); (ii) collections made by Dr. J. G. 
Wessels Boer (WB) in Central and South America (as in Wessels Boer 1965); (iii) collections made by Professor H. E. Moore (HEM), also from Central and South America, together with some material provided by him from other people's collections. Identification to species was made as far as possible in Henderson (2000), in which there is an extensive list of synonyms, many used originally in our source material but

Table 1. Source material of Bactris stem specimens. Listed alphabetically in the informal groups of Henderson (2000) and their total number of species. HEM: H.E. Moore; WB: J. Wessels Boer; PBT: P.B. Tomlinson; ?: The original collection has an unclear or uncertain location. There may be some inaccuracy in the location, but where the location is labeled with a question mark and a country, it is an educated guess based on where the collector conducted his research.

\begin{tabular}{|c|c|c|}
\hline Species & Collection & Location \\
\hline \multicolumn{3}{|l|}{ Amylocarpus group (7 spp.). } \\
\hline \multicolumn{3}{|l|}{ B. hirta Martius } \\
\hline var lakoi (Burret) Henderson & HEM et al. 8423 & Peru \\
\hline var spruceana (Trail) Henderson & WB $1584 \& 1615$. & Suriname? \\
\hline B. simplicifrons Martius & PBT 2 VII 62B & Trinidad \\
\hline \multicolumn{3}{|l|}{ Orange-fruited group (16 spp.). } \\
\hline \multirow{2}{*}{ B. campestris Poeppig ex Martius } & PBT 2 VII 62C & Trinidad \\
\hline & WB $594 \& 1515$ & Suriname \\
\hline B. hondurensis Standley & PBT 15 VIII 65 & Costa Rica \\
\hline \multicolumn{3}{|l|}{ Guilielma group (6 spp.) } \\
\hline B. gasipaes Kunth var gasipaes & PBT 13 III 61 & FTG. \\
\hline B. jamaicaina L.H. Bailey & WB 1663 & Jamaica \\
\hline B. setulosa H. Karsten & WB $1636 \& 1637$ & Trinidad \\
\hline \multicolumn{3}{|l|}{ Piranga group (9 spp) } \\
\hline \multirow{2}{*}{$\begin{array}{l}\text { B. acanthocarpoides Barbosa } \\
\text { Rodrigues }\end{array}$} & WB 644 & Suriname \\
\hline & WB 382, 1432 \& 1609 & Suriname? \\
\hline B. halmoorei Henderson & HEM 8460 & Peru \\
\hline \multicolumn{3}{|l|}{ Purple-fruited group (27 spp.) } \\
\hline \multirow{2}{*}{ B. constanciae Barbosa Rodrigues } & WB 189 & Suriname \\
\hline & WB 275 & Suriname? \\
\hline \multirow{2}{*}{ B. elegans Barbosa Rodrigues } & Bailey 224 & Suriname \\
\hline & WB 1154 & Suriname \\
\hline B. guineensis (L.) H.E. Moore & WB 1610 & Suriname \\
\hline B. maraja Martius var maraja & WB 576, 577, 927 & Suriname \\
\hline B. sphaerocarpa Trail & HEM et al. 8421 & Peru \\
\hline \multicolumn{3}{|l|}{ Pyrenoglyphis group (8 spp.) } \\
\hline B. brongniartii Martius & WB 344, 468, 475, 701, 1034 & Suriname \\
\hline \multirow{2}{*}{ B. major Jacquin } & WB 1633, 1641 & Trinidad \\
\hline & WB 190, 343, 344, 429 & Suriname \\
\hline \multicolumn{3}{|l|}{ Unidentified species } \\
\hline Bactris sp. & HEM 9406 & $?$ \\
\hline Bactris sp. & PBT 15 VIII 65F & Costa Rica \\
\hline Bactris sp. & PBT 15 VIII 65K & Costa Rica \\
\hline Bactris sp. & PBT 7 VII 62 AC & Trinidad \\
\hline Bactris sp. & HEM 9406 & $?$ \\
\hline
\end{tabular}



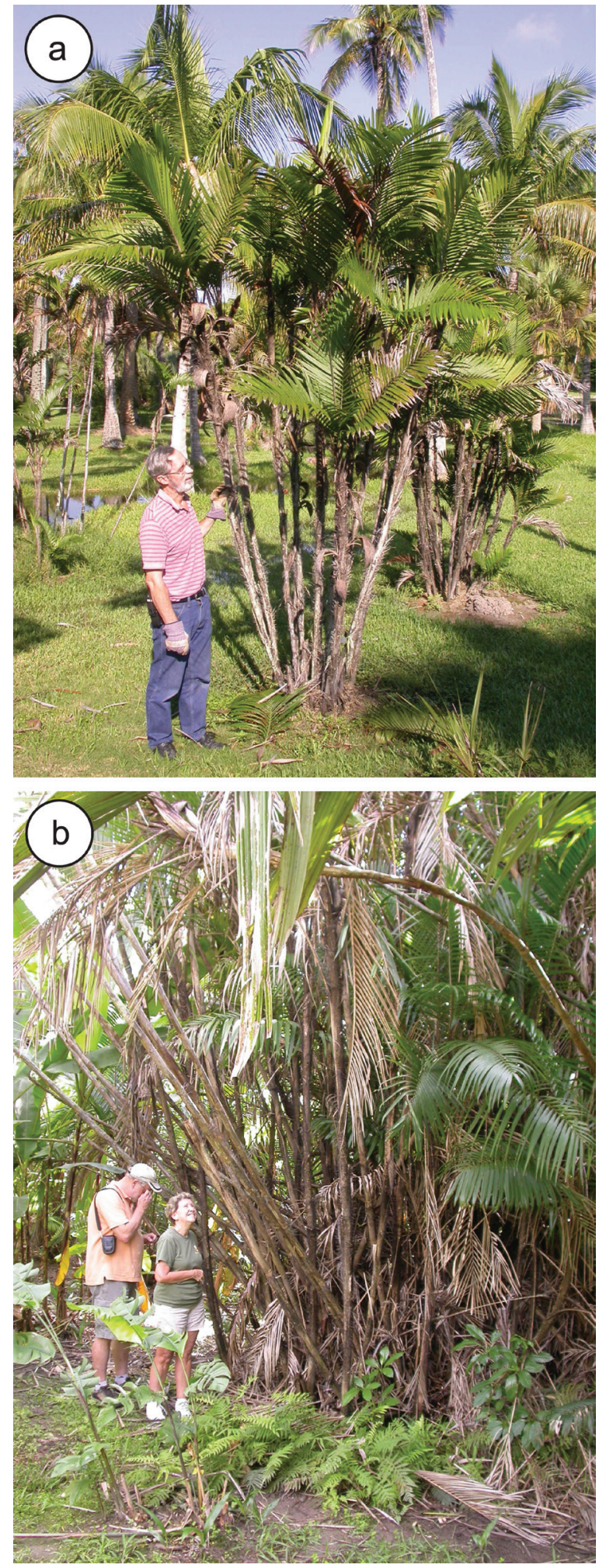

Figure 1. Bactris major in cultivation. a. At Montgomery Botanical Center, Coral Gables Florida; young specimen, accession number $94582 * \mathrm{G}$, source Venezuela, $17 \mathrm{yr}$ from planting. Larry Noblick for scale. b. At Fairchild Tropical Botanic Garden, Coral Gables Florida; mature specimen, source British Guiana, accession number 57819A, 50 yr from planting. Mary Collins and David Lee for scale. subsequently corrected. The use of Henderson's nomenclature thus simplifies what otherwise could be a misleading set of names. The Wessels Boer material was received dried, some of it with collection numbers not found in Henderson (2000); mostly other material was field-fixed in formalin-acetic-alcohol (85 parts $70 \%$ ethyl alcohol, 10 parts glacial acetic acid, 5 parts $40 \%$ formaldehyde). Dried material was rehydrated before further processing by boiling in tap water with added detergent.

Immature material refers to fluid-fixed apical stem portions just below the leafy crown; mature material refers to more basal portions, although this does not necessarily imply that all cell types were completely differentiated. The most obvious exception was the necessary, complete early maturation of vascular elements, i.e., tracheary elements and sieve tubes. Material was sectioned in transverse and longitudinal planes with a sliding microtome, usually after preliminary desilicification in $50 \%$ hydrofluoric acid. Much material was embedded in celloidin prior to sectioning (Tomlinson et al. 2011). Stains, either in combination or singly included safranin and Delafield's hematoxylin, safranin and fast green, tannic acid and resorcin blue, crystal violet, and Bismarck brown (Tomlinson et al. 2011), their various applications indicated in the figure legends. The natural color of an unprocessed stem cut in TS is of a black outer layer and brown center (figure 3 a). Extensive artifacts include frequent scoring by the microtome knife of the exceedingly sclerotic older stem parts, together with disorganization and tearing of central ground tissues (brown in figure $3 \mathrm{~b}$ ). Microscopically there is frequent displacement of cell contents (e.g. starch grains carried into tracheary elements). Material from the tropics dried in the field often included fungal hyphae and spores together with partly digested starch grains. Phloem is frequently degraded. For celloidin sections, the embedding matrix usually retained one of the stains as background color.

Maceration using boiling $10 \%$ caustic potash (KOH) followed by $20 \%$ chromic acid (aqueous chromium trioxide, $\mathrm{CrO}_{3}$ ) produced isolated cell types. This gave evidence of contrasted fiber types (figure $4 \mathrm{k}$ ) and information about types and frequency of perforation plates in metaxylem vessel elements.

Photographic images were made with a Nikon Coolpix 4500 digital camera and processed in Adobe Photoshop and Adobe Illustrator. 


\section{Results}

\section{Immature Stems}

General stem anatomy - Vascular construction, as observed in single sections, corresponds to the basic Rhapis model of Zimmerman and Tomlinson (1965), although we made no extended three-dimensional analysis to confirm this as the material was unsuitable for the production of serial sections. Otherwise there is a distinct cortex, as narrow as eight cell layers wide in smaller species (figure 2a). In larger species the wider cortex includes numerous fiber bundles together with outgoing leaf traces (figure $2 \mathrm{c}, \mathrm{LT}$ ). The central cylinder, as in all palms, is delimited from the cortex by the abrupt transition to crowded peripheral axial bundles but without any specialized limiting layer (white arrows in figure $2 \mathrm{c}$ ). Each outer bundle has a massive fiber sheath external to the phloem, the crowded bundles separated from each other by narrow bands of ground parenchyma (figure $2 \mathrm{a}, \mathrm{c}$ ). This outer bundle complex ultimately forms the chief mechanical tissue of the stem and is progressively augmented with age by continued secondary wall thickening of vascular fibers and intervening ground parenchyma cells. Immediately within the sub-peripheral part of the central cylinder, vascular bundles are less congested and with the fibrous sheath of each reduced, leading to the diffusely distributed vascular bundles of the stem center (figure $2 \mathrm{~b}$ ). In wider stems outer bundles of the central cylinder are numerous and congested (the periphery, figure $2 \mathrm{c}$ ) with a progressively more diffuse transition region (the sub-periphery, figure $2 \mathrm{~d}$ ), which in turn contrasts with the wide stem center (figure $2 \mathrm{~b}, \mathrm{e}, \mathrm{f}$ ). In the mature stem the contrast between soft inner and hard outer regions is both mechanically and hydraulically efficient.

Central bundles have a narrow bundle sheath and show the greatest diversity of tracheary elements in terms of protoxylem and metaxylem (cf figure $2 \mathrm{c}, \mathrm{d}$ with e, f). This diversity reflects the longitudinal changes along each bundle according to the uniform features of the Rhapis model (Tomlinson 1990). These include the single metaxylem vessel at the basal end of each bundle (corresponding to the peripheral congested bundles, e.g. figure $2 \mathrm{c}$ ), which usually becomes two or more wide vessels distally (e.g. figure $2 \mathrm{~d}-\mathrm{f}$ ), together with the progressive distal increase in number of protoxylem elements, these eventually being the sole supply in the outgoing leaf trace. The contrast in the stem center between an outgoing leaf trace (LT) and an adjacent inwardly diverging axial bundle (AB) is shown in figure $3 \mathrm{~h}$. Metaxylem vessels provide axial hydraulic continuity along the stem whereas leaves are supplied via protoxylem tracheids. Bridge bundles, which connect outgoing leaf traces to axial bundles and inflorescence traces diverging from leaf traces, complete the transport pathways. These features, so succinctly described, are features of all palm stems.

The level within a vascular bundle at which the metaxylem changes from a single to two or more wide vessels varies in different species, or even samples, such that a conventional distinction between "onevessel" and "two vessel" palms is made (Tomlinson et al. 2011) and to some extent used as a diagnostic character. In our material, this feature varies in different species or even samples, but figure 4 e may be cited as an imperfect example of a "two-vessel" palm. The one-vessel condition seems most frequent in narrow stems, which could be a simple topographic consequence of a shorter axial distance over which the change from one to two metaxylem vessels can be made.

Ground tissue - The ground tissue of immature stems is uniformly parenchymatous but early develops wide intercellular spaces as cells expand horizontally and separate, producing a somewhat honeycomb pattern as seen in TS (figure $2 \mathrm{f}$ ) but better revealed in LS as axially extended air spaces (figure $2 \mathrm{~g}$ ). These continue to enlarge (figure $2 \mathrm{~h}$ ) and are the precursor to a well-developed system of air-lacunae that characterize all but the narrowest stems. As described later, development of air spaces usually produces an entirely different texture in the stem center.

Idioblastic elements - A feature of the ground tissue in stems of all ages is the presence of scattered tannin cells easily identified by their dark contents (figure $2 \mathrm{e}, \mathrm{f}$ ). They are differentiated early and persist in subsequent stages of tissue development, but rarely undergo late cell expansion. They are uniformly distributed but vary in abundance in different species; in figure 2 a and $2 \mathrm{~b}$ they appear to be absent. An exception to the general diffuse distribution of tannin cells was seen in B. gasipaes, in which they occur in linear series (figure $2 \mathrm{~g}$ ), and distinguished from raphide sacs by the absence of crystalline material.

Raphide sacs are rarely observed, but an exceptional occurrence of axially elongated raphide sacs with densely stained cytoplasmic contents was found in B. gasipaes. 

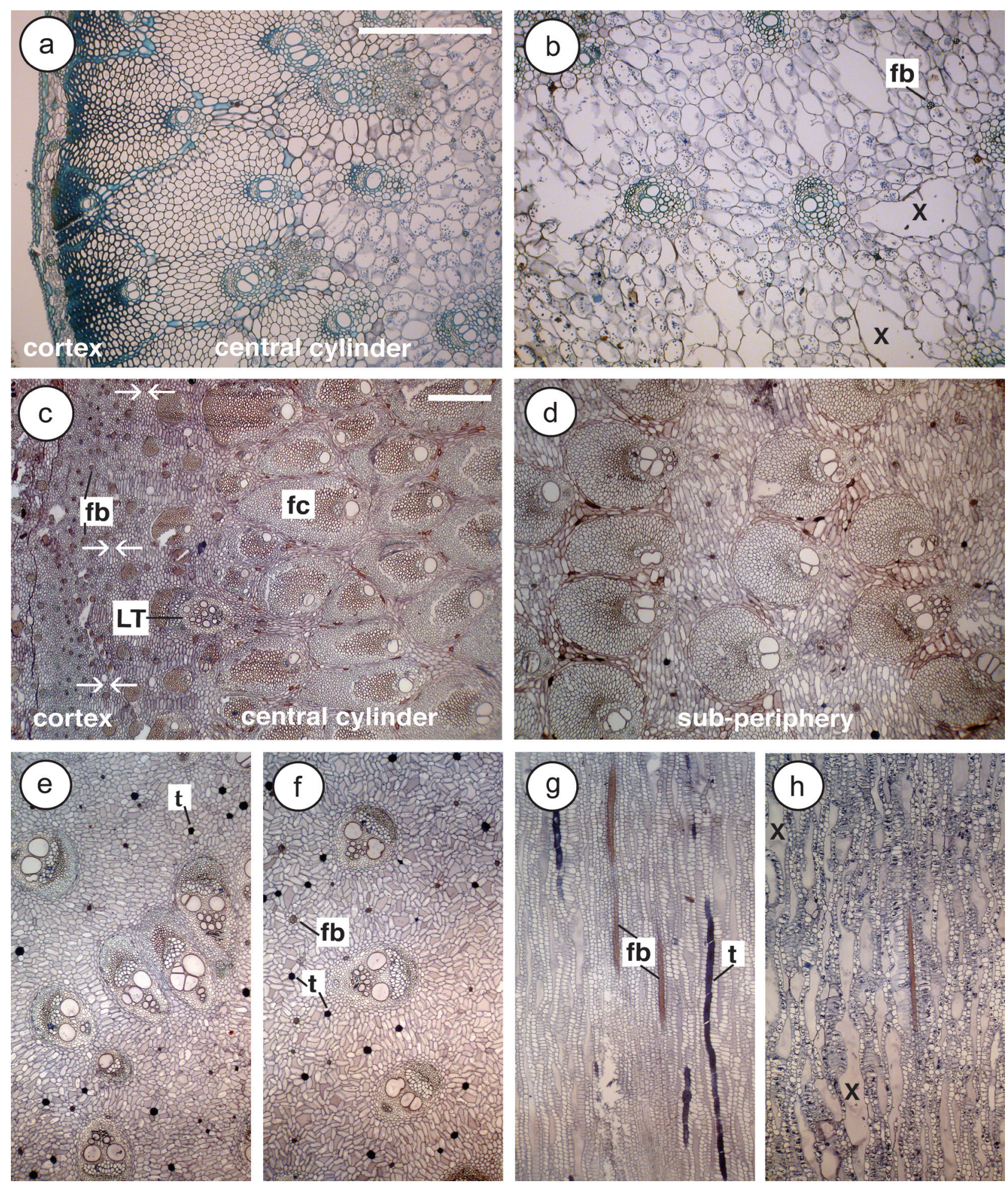

Figure 2. Bactris spp., stem anatomy in early development, all stained in tannic acid and resorcin blue stain. TS in a-f. LS in g, h. B. simplicifrons ( $\mathrm{a}$ and $\mathrm{b}$ ), stem overall diameter $6 \mathrm{~mm}$. a. Periphery of central cylinder, few outer fibers mature. b. Stem center with limited early development of air-lacunae and cell expansion; fiber bundles narrow with few cells, obscure at low magnification (see figure $4 \mathrm{~g}$ for closeup view). c-h. B. gasipaes. Stem periphery, overall diameter $20 \mathrm{~cm}$. c. Fiber caps of vascular bundles with limited wall maturation. d. Stem sub-periphery, fiber caps of vascular bundles thin-walled except near phloem of peripheral bundles; ground tissue cells with some horizontal expansion. e. Stem outer center, fiber caps narrower with some wall thickening near phloem. f. Stem center, fiber caps narrow and immature; ground parenchyma cells expanded to form wide intercellular spaces. g. Stem center in LS, air spaces extensively elongated and conspicuous. h. Stem center at a later stage in LS with cell collapse to form air-lacunae. Scale bars: $500 \mu \mathrm{m}$ in a, same for b; $500 \mu \mathrm{m}$ in c, same for d-h. fb - fiber bundle, fc - fiber cap, LT - leaf trace, t - tannin cells, X - air lacunae. 
As in all palms, stegmata (silica cells) are present, always in association with fiber bundles. The silica bodies are of a type designated "hat-shaped" but found in only few tribes, as here in all Bactridineae. They occur most obviously in Bactris as a usually complete investment of small cells around the nonvascular fiber bundles, but are much less frequent adjacent to vascular fibers, possibly by virtue of the late maturation of such cells.

Fiber types - Fibers are of two contrasted types, those forming the bundle sheath on the phloem side of the vascular bundles (vascular fibers) and those forming an independent series of pure fiber strands (nonvascular fibers). A contrasted developmental feature of these two types of fiber is that the latter mature rapidly, but vascular fibers continue to mature over an extended period, as detailed below. Structurally the two fiber types are very distinct; vascular fibers (figure $4 \mathrm{k}-\mathrm{vb}$ ) are wide and long, but with the wall becoming progressively thickened, lamellate and lignified, as described later; non-vascular fibers are short, narrow and unlignified (figure $4 \mathrm{k}-\mathrm{fb}$ ).

Non-vascular fiber bundles form a diagnostic feature for Bactris stems and occur in the subperipheral and central region as an independent series of non-anastomosing, i.e., strictly axial strands scattered throughout the ground tissue. The majority of stems we investigated show conspicuous development of this independent series of fiber bundles (e.g. figure $3 \mathrm{~g}-\mathrm{fb}$ ), but in narrower stems, e.g., B. simplicifrons, such fibers may not be apparent in a small sample (figure $2 \mathrm{~b}$ ) and can only be seen at high magnification (figure $4 \mathrm{~g}$-fb). Otherwise, the range of fiber bundle diameter is determined by the number of constituent cells seen in a single section, from as few as 2-8 in narrow fiber strands (figure $4 \mathrm{~g}$-fb), but over 100 in larger strands (figure $4 \mathrm{f}$ ). Fiber bundles show a wide variation in diameter as seen in TS, sometimes within a single stem (figure $3 \mathrm{f}, \mathrm{g}-\mathrm{fb}, \mathrm{j}, \mathrm{k}$ ), but among different species they may be somewhat diagnostic. The individual non-vascular fibers (figure $4 \mathrm{~K}-\mathrm{fb}$ ) usually have a narrow diameter (5 to $7.5 \mu \mathrm{m}$ ) and a very narrow cell lumen and lack wall lignifications in contrast to the wider diameter of vascular fibers, which when mature become lignified with diameters in the range of 20-40 $\mu \mathrm{m}$ and conspicuous lamellation of cell walls as seen in TS (figure $4 \mathrm{~h}$ ). Macerations show that the narrow cells of the fiber bundles are also shorter than those of the bundle sheath, the nonvascular fibers as short as $1.0 \mathrm{~mm}$. Maturation within larger fiber strands starts at the bundle periphery and progresses towards its center.

\section{Maturing Stems}

The primary histological features of the stem are progressively modified but largely without the addition of new tissues, most noticeably in the behavior of the parenchymatous ground tissues and the vascular fibers. Vascular tissues show no change with age except that which is normal in the developmental difference between proto- and meta-xylem, on the one hand, and proto- and meta-phloem, on the other. Protoxylem shows varying degrees of disruption according to the extended period over which it is differentiated; protophloem is soon occluded to leave a single metaphloem strand, but its position can be recognized as the site where bundle sheath fibers first mature. Protoxylem elements are always tracheids, metaxylem consists of vessels of varying diameter, all of which are features common to all palms. In Bactris metaxylem vessel elements usually have transverse or slightly oblique end walls with a mixture in varying degrees of simple and scalariform perforation plates with very few (1-8) thickening bars. Tyloses are rare.

Enlargement of intercellular lacunae - If upper and lower regions of one stem are compared, developmental changes with age can be inferred (figure 3). A more accurate method would be to compare the same basal region of an old, tall stem with that of a younger short stem. An ideal destructive sampling of the same region at different ages is not possible because wound responses are induced. Otherwise, as with all palms the maturation of cell types takes place over long distances. From our sampling of stems of different species and ages, we were able to establish a common developmental pattern for all species, which varies somewhat in its expression with stem diameter.

Cell expansion is most marked in regions away from central vascular bundles; it is not uniform and can produce a mixture of large and small cells. Cells remain unexpanded adjacent to vascular bundles, which consequently retain a surrounding of narrow cells (figure $3 \mathrm{~g}$, $\mathrm{k}$; later stage seen in detail in figure $3 \mathrm{~h}$ ). A radiating pattern of cells is seen in TS in early expansion (figure $3 \mathrm{j}$ ). At the most extreme a narrow sheath of small ground parenchyma cells is contrasted with a very lacunose ground tissue (figure $3 \mathrm{n}$ ). Tannin cells (black cells in figure $2 \mathrm{e}, \mathrm{f}$ ) rarely expand and so can be used to estimate how much expansion other cells have undergone. A good example is shown in 

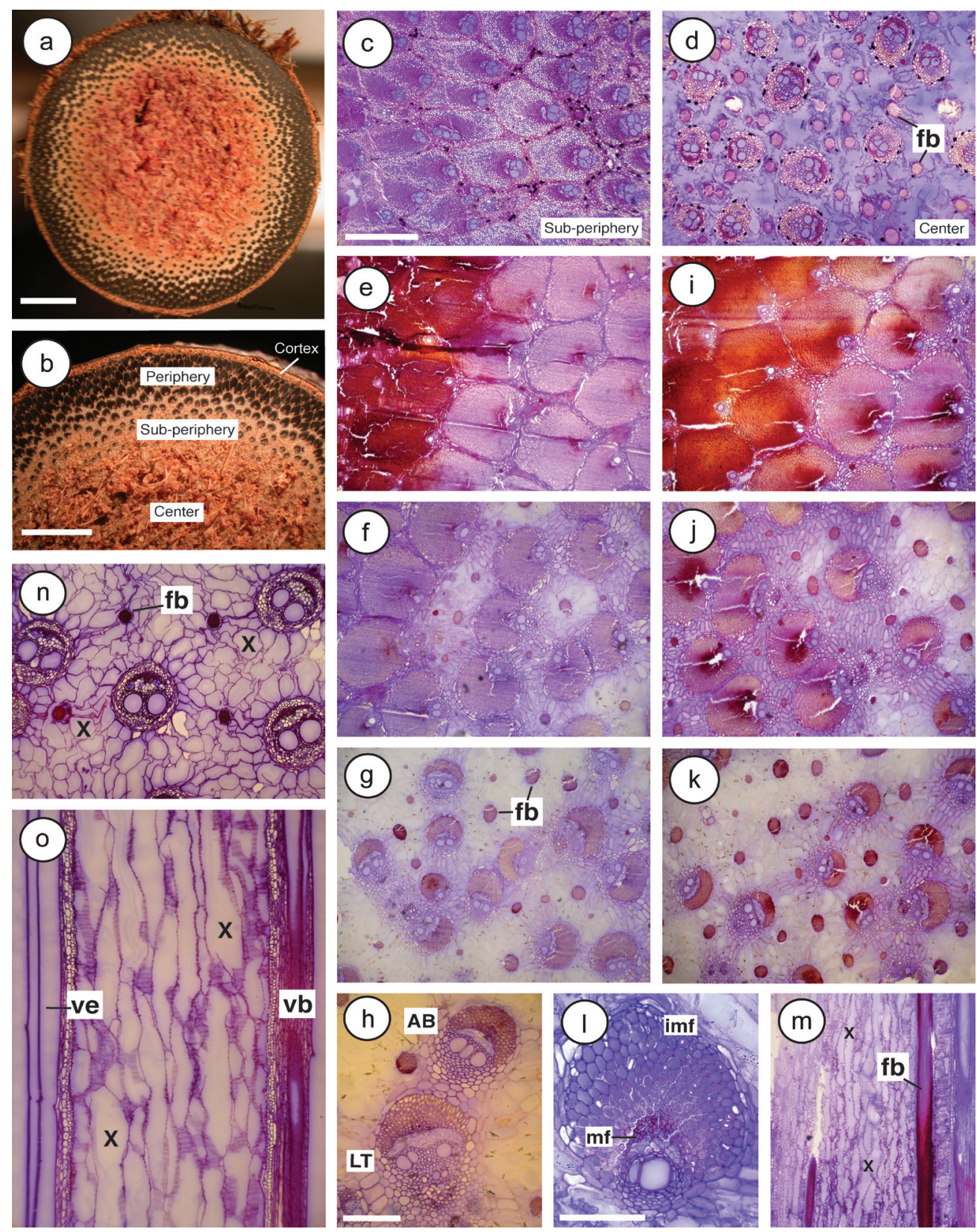

Figure 3. Bactris spp., maturing and mature stems; TS in a-1, n; LS in $\mathrm{m}$ and o. In c-m stained in crystal violet; stem periphery to left in $\mathrm{c}-\mathrm{f}$, and i, j; lignified fibers black in a and b, brown color natural in e and i. a, b, B. major. Sawn mature stem from figure 1 a, diameter $25 \mathrm{~mm}$, outer vascular bundles with heavily lignified (black) fiber caps, central tissue disrupted. b. Detail of regions referred to in text. c, d. B. constanciae. Maturing stems. c. Sub-periphery, fibers of bundle cap progressively immature towards stem center. d. Center, vascular bundles with narrow cap of mature fibers; fiber bundles wide and abundant, disorganized ground tissue an artifact of sectioning. e-m. B. acanthocarpoides. e-h. Maturing stem. e. Periphery, only outer vascular bundles with mature fibers. f. Sub-periphery, innermost vascular bundles with decreasingly narrow fiber caps. g. Center, fiber caps of vascular bundles well developed but with limited wall thickenings, ground tissue cells near vascular bundles stained because of early wall thickening. h. Center, leaf trace (LT) below, axial bundle (AB) above, contrasting amount and maturity of fiber cap. i-m. More mature stem. i. Periphery with progressive maturation of bundle cap fibers toward stem center. j. Sub-periphery, progressive maturation of fiber caps towards stem center (cf figure $3 \mathrm{f}$ ); ground tissue cells thicker-walled in association with vascular bundles. k. Center, with maturing caps to vascular bundles; conspicuous fiber bundles; unstained thin-walled cells of ground tissue showing early collapse. 1 . TS vascular bundle of stem periphery showing progressive maturation of fibers, mature (mf) near phloem, immature (imf) distant from phloem. m. LS of ground tissue of older stem. n, o. B. jamaicana. n. TS mature stem center, collapsed ground tissue cells forming wide air-lacunae, giving appearance of large single cells. o. LS mature stem, ground tissue between two vascular bundles (ve and vb) including wide longitudinally extended air-lacunae, individually delimited by collapsed cells. Scale bars: $5 \mathrm{~mm}$ in a, same for b; $500 \mu \mathrm{m}$ in c, same for d; e $500 \mu \mathrm{m}$, same for f-k, i-o except $200 \mu \mathrm{m}$ in h, and $250 \mu \mathrm{m}$ in 1 . AB - axial bundle, $\mathrm{fb}$ - fiber bundle, imf - immature fibers, $\mathrm{mf}$ - mature fibers, LT - leaf trace, vb - vascular bundle, ve - vessel element, X - air-lacunae. 
figure $4 \mathrm{a}$ and $\mathrm{b}$, the tannin cells never reach the maximum size of other parenchyma cells, either transversely (figure 4 a) or longitudinally (figure 4 b).

Cell expansion varies according to stem diameter. It is limited in narrow stems but extensive in wide stems, producing lacunae seen in LS as elongated spaces (figures $2 \mathrm{~g}, \mathrm{~h} ; 3 \mathrm{~m}$ ). A major contribution to the formation of these air-lacunae is collapse of plates of parenchyma cells. This increases internal air-space considerably but without increase in overall stem diameter. A transverse view (figure $3 \mathrm{n}$ ) suggests wide single cells, rather than intercellular lacunae, until the tissue is examined in longitudinal section whereupon the lacunae are seen as elongated spaces, much longer than single cells, surrounded by vertical plates of collapsed cells (figure 3 o).

Cell expansion and formation of air lacunae is limited to central regions. Sub-peripheral regions show some expansion but without large lacunae; peripheral ground tissue may expand and appear compressed between the massive fibrous sheath of maturing bundles (figure $4 i, j$ ). Such compressed cells eventually develop thickened and lignified cell walls with conspicuous pits. We have examined insufficient material of old stems that would allow us to observe wall thickenings in central ground tissue cells. Such changes may occur first in cells near the vascular bundles as suggested by the pattern of stained and unstained cells seen in figure $3 \mathrm{~g}$ and $\mathrm{k}$.

Fiber development - Bundle sheath fibers are laid down in larger or smaller numbers according to the level a vascular bundle within the central cylinder is selected, those associated with peripheral bundles being most numerous (cf. figure 2 a versus $2 \mathrm{~b}$ and figure $3 \mathrm{c}$, d versus $3 \mathrm{e}, \mathrm{f}$ ). Bundle sheaths (fiber caps in TS) are therefore always considerably wider in peripheral bundles. The individual fibers initially have a wide lumen and a thin wall and their number is completed early in vascular bundle development (figure 2a). We have no evidence that the bundle sheath can be enlarged by apical intrusive fiber growth at a later stage; the number of the bundle sheath fibers in any one vascular bundle at any one level in the maturing stem remains constant.

Special features - Additional variants on these general features are shown in the mature stems of two contrasted species of which only limited material is available. In Bactris guineensis (figure $4 \mathrm{a}, \mathrm{b}$ ) the ground tissue appears to be without air-lacunae, because if they ever existed they have become occupied by cells resulting from division of contiguous cells whose expansion results in an irregular tissue of large and small cells. No collapse to form cell plates is involved.

In Bactris hirta var. spruceana, the outer vascular tissue behaves in the usual way (figure $4 \mathrm{c}$ ), but in the inner stem there is an initial transverse cell expansion but without any cell collapse that could develop wide air lacunae. The result is a pattern of mature parenchyma cells with thickened walls that radiate around the vascular bundles as seen in TS (figure $4 \mathrm{~d}$, e) a condition that is common in many palms.

\section{The Mature Stem}

The mechanical support provided by the collective fiber sheath of all peripheral stem bundles is lacking in young and still extending internodes. Consequently, the early mechanical support for the palm crown is provided by the richly fibrous collective sheathing leaf bases of outer (i.e., older) leaves. With eventual leaf loss the stem bundles assume sole mechanical support and this requires maturation of stem fibers by cell expansion (figure 31 ) and cell wall thickening and lignification. As we have seen, this commences first in the outermost bundles of the central cylinder (figure 3 e, i). Fiber maturation always begins in the sheath fibers adjacent to the phloem and progresses radially outwards toward the bundle sheath periphery (figure 31 ), but slowly and over a distance of many internodes. Wall thickening is accompanied by lignification so that the mechanical ability of the stem progressively increases as the outer layers of the central cylinder become more rigid. Overall, and most obviously, in the upper internodes of a stem there is a radial progression of fiber maturation from outer to inner bundles as seen by comparing figure $3 \mathrm{e}$ (outer) with $3 \mathrm{f}$ (inner) and $3 \mathrm{i}$ (outer) with $3 \mathrm{j}$ (inner). The change in fiber histology is mostly marked when young and old stages of the same species are compared (figure $4 \mathrm{i}$ versus $4 \mathrm{j}$ ). In older fibers the result of this progressive wall deposition and lignification is shown in TS as a thick secondary wall with concentric layering (figure $4 \mathrm{~h}$ ), suggesting abrupt changes in microfibril orientation.

The complete mechanics of the stem are realized at the base of a tall stem. This consists of a narrow peripheral cylinder of extremely sclerotic tissue made up of the combined sheaths of outermost vascular bundles together with the intervening compressed lignified ground parenchyma. Towards the stem center vascular bundles, are more diffuse and with reduced bundle sheaths. The central tissue, with widely spaced 

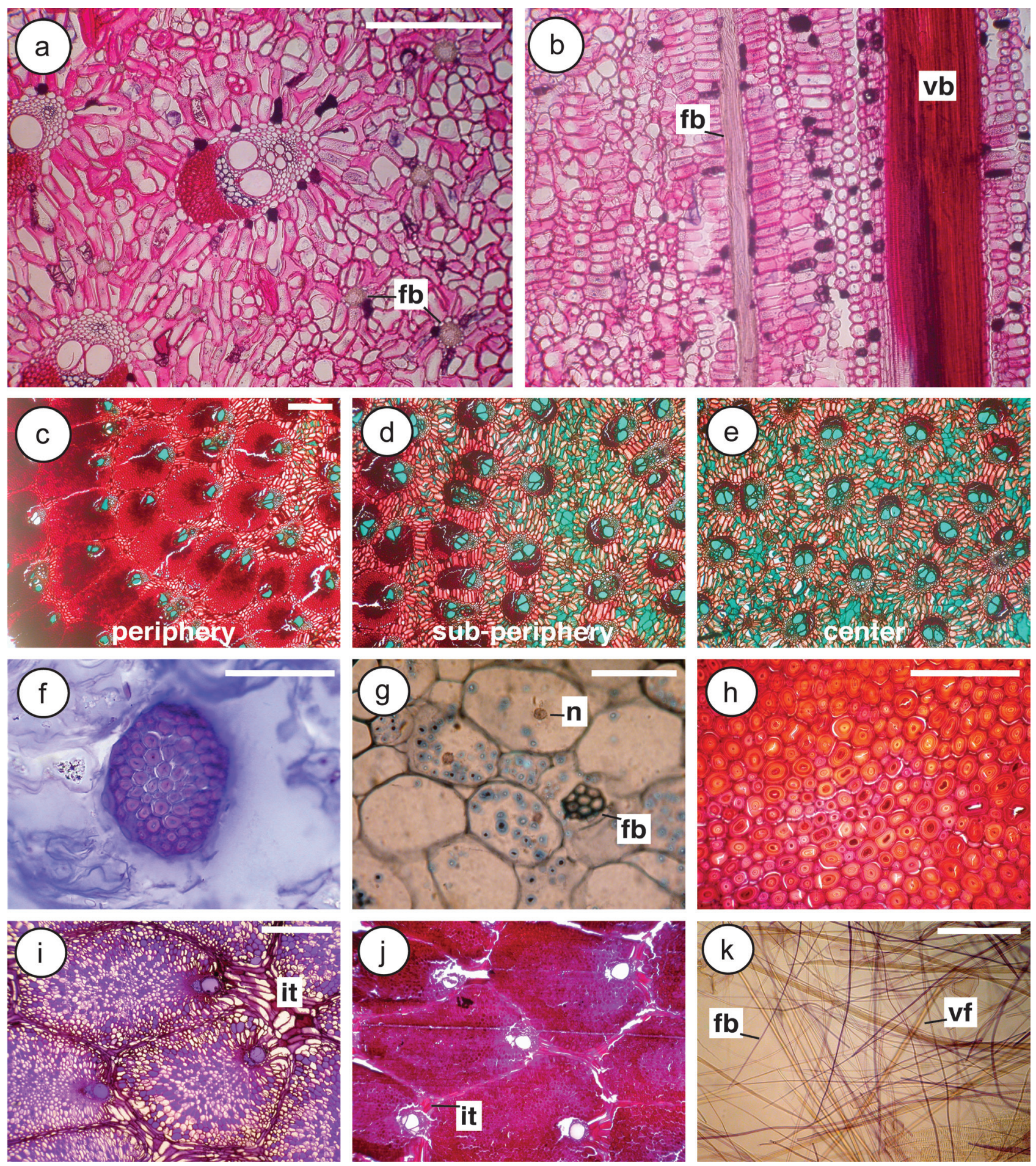

Figure 4. Bactris spp. Stem structural and developmental details a, b. B. guineensis stained in safranin and Delafield's hematoxylin. a. TS center, without air-lacunae but secondary division of ground tissue cells. b. LS center to confirm absence of air-lacunae. c-e. B. hirta stained in safranin and alcian green. c. TS periphery with mature tissues. d. Sub-periphery, transitional to center. e. Mature stem center, ground tissue with enlarged intercellular spaces but no air-lacunae. f-h. Fiber types. f. B. acanthocarpoides. Fiber bundle in stem center (c. 80 visible cells). g. B. simplicifrons. TS fiber bundle ( 8 visible cells) from stem center, ground tissue with starch grains and visible nuclei (arrowheads). h. B. acanthocarpoides. TS mature fiber sheath cap from peripheral vascular bundle, wider part of fibers show stratified secondary cell wall. i-j. B. setulosa. Immature vascular bundles from periphery with extended thin-walled cells of intervening ground tissue. j. Mature peripheral vascular bundles, intervening ground tissue now thick-walled. k. B. major. Macerated fibers contrasting vascular (vf) and non-vascular (fb). Scale bars: $500 \mu \mathrm{m}$ in a, same for b, $500 \mu \mathrm{m}$ in c, same for d, e; $100 \mu \mathrm{m}$ in f; $50 \mu \mathrm{m}$ in $\mathrm{g} ; 100 \mu \mathrm{m}$ in h, $500 \mu \mathrm{m}$ in $\mathrm{i}$, same for $\mathrm{j}, 250 \mu \mathrm{m}$ in $\mathrm{k}$. fb - non-vascular fibers, it - intervening ground tissue; $\mathrm{n}$ - nucleus; vf - vascular fibers. 
vascular bundles is relatively soft and spongy, with limited sclerosis, together with the independent fiber strands. This contrast between extremely hard outer layers and soft central regions, though mechanically highly efficient, makes such palm stems difficult objects for anatomical study. At the same time it suggests that older stems are likely to be most frequently preserved as fossils.

Variation with stem diameter

Stem diameter among Bactris species varies more than an order of magnitude, from $5 \mathrm{~mm}$ to $25 \mathrm{~cm}$, and even within a single clump of one individual there can be an appreciable range in different stems arising from the rhizome system. In principle the histological changes we describe occur in all stems but with increasing expression in wider stems. Narrow stems remain less lacunose, wider stems become more lacunose and appear more disorganized with age. Quantitative differences determined by stem diameter include narrow vascular tissues, especially metaxylem elements, in narrow stems.

Diagnostic features in contrasted species

Our survey has been too limited to allow an assessment of the informal groups of Henderson (2000), but we can present a brief comparative overview in their context.

Amylocarpus group - Stems narrow (up to $2 \mathrm{~cm}$ diameter) and short (less than $3 \mathrm{~m}$ tall); metaxylem vessel elements with mostly scalariform perforation plates; non-vascular fiber bundles either narrow and infrequent (B. simplicifrons) or massive and numerous (B. hirta var spruceana); one- and two-vessel types present. Raphide sacs conspicuous in B. simplicifrons.

Guilielma group - Stems wide (up to $25 \mathrm{~cm}$ diameter and $18 \mathrm{~m}$ tall); non-vascular fiber bundles either frequent and wide as in B. jamaicana and B. setulosa, or few in B. gasipaes; air-lacunae not formed in $B$. setulosa; perforation plates of metaxylem vessel elements mostly scalariform, except mostly simple in $B$. jamaicana; mostly two-vessel types.

Orange-fruited group - Stems narrow (up to $4 \mathrm{~cm}$ diameter and $5 \mathrm{~m}$ tall); non-vascular fiber bundles numerous and wide, air-lacunae absent from $B$. hondurensis; perforation plates of vessels scalariform or simple; one- or two-vessel type.

Piranga group - Stems narrow (up to $5 \mathrm{~cm}$ diameter and $8 \mathrm{~m}$ tall); fiber bundles numerous and wide, perforation plates of vessels always simple; most consistently two-vessel palms.

Purple-fruited group - Stems narrow (up to $4 \mathrm{~cm}$ diameter); non-vascular fiber bundles numerous and often wide; perforation plates of metaxylem vessels simple or compound; one- or two vessel types; ground tissue parenchyma cells secondarily divided to fill air-lacunae in B. guineensis.

Pyrenoglyphis group - Stems moderate (to $8 \mathrm{~cm}$ diameter and $10 \mathrm{~m}$ tall); fiber bundles well developed; perforation plates of metaxylem vessel elements most consistently simple; mostly two-vessel type.

\section{Discussion}

The picture built up from these many components demonstrate within Bactris a consistency of stem anatomical features and their development even within a wide range of stem diameters. This could have provided an example where stem anatomy might have been of value in the classification of palms, a question debatable in the absence of any comparable study within a large genus. Despite our study, the question is still unresolved. However, we do find a number of features that characterize most of the species we studied, but we do not find consistent evidence that supports the informal groupings suggested by Henderson (2000). A similar lack of evidence for monophyly among Henderson's groups is provided by the molecular systematic analyses of Eiserhardt et al. (2011), albeit from a somewhat smaller sample size than ours. Only the Guilielma group seems to be a contender for monophyletic status, possibly a consequence of the size of individuals, but also the best circumscribed in terms of morphology (e.g. Sanders 1991). The most obvious diagnostic feature is the presence of a system of fiber bundles within the ground tissue of the stem center, although this is not expressed uniformly in all taxa. However, this arrangement is not unique to Bactris. Similar fiber bundles with the same distinctive fiber type occur in other Bactridinae, e.g. Acrocomia and Astrocaryum, suggesting a plesiomorphy for this clearly monophyletic tribe. Desmoncus, a climbing palm, possible sister taxon to Bactris, lacks such stem fibers (Tomlinson and Zimmermann 2003). Their absence might be seen as phyletic loss correlated with the climbing habit that characterizes Desmoncus. However, Eisenhardt et al. (2011) conclude that the true inter-generic relationships among the genera of Bactridinae must still be an open question. 
An independent system of non-vascular fibers also occurs in several unrelated palm tribes; ten genera were reported in Tomlinson (1961). From this we know that isolated fiber strands occur in the stem ground tissue of some representatives of all palm subfamilies except Nypoideae. However, this distinctive short, narrow and unlignified stem fiber, found in the Bactridinae, seems unique to this subtribe. A nonvascular fiber bundle system occurs widely in petioles in many genera of palms in more distant groups, but its distribution has not been explored in detail throughout the family. This is a further example of the extensive homoplasy in palms reported in Tomlinson et al. (2011). A functional explanation for the distribution of these independent fiber strands embedded within parenchymatous ground tissue has still to be found.

The development of a system of wide airlacunae in the stem ground tissue of Bactris species needs discussion in a wider context. We have shown (figure 2) that these internal lacunae originate initially as intercellular spaces that become widened by transverse cell expansion, followed by collapse of vertical plates of cells so that there is a longitudinal space extension. This can appear superficially in TS as if the ground tissue is occupied by very wide cells (figure $4 \mathrm{n}$ ) and this has so been described by Thomas (2011) and Thomas and De Franceschi (2013) who did not examine longitudinal sections. The feature may be diagnostic for Bactris, and is most striking in wider stems but does not occur in all species. In B. guineensis, from a single sample, air-lacunae do not appear in a mature stem because extensive late cell division apparently infills the intercellular space system (figure $4 \mathrm{a}, \mathrm{b}$ ). The only other example of late cell division infill reported so far was described for Normanbya normanbyi (A.W.Hill) L.H. Bailey. (Arecoides, Ptychospermatinae), a Queensland palm not closely related to Bactris (Tomlinson et al. 2011 figure 17). Bactris hirta is another exception without wide air-lacunae, provided our material has been correctly identified.

Developmentally, the pattern of fiber maturation in stems of Bactris is intrinsically the same in all examined species, showing a high consistency of this aspect of sustained primary growth and needs to be discussed in the wider context of palm stem structure and development. Several typologies for the anatomy of the palm stem exist, as summarized extensively by Thomas (2011) and Thomas and De Franceschi (2013). They emphasize two distinct forms; first those with a relatively uniform distribution of vascular bundles within the ground tissue of the central cylinder (their Type A) and those in which the central bundles of the central cylinder have a much more diffuse distribution of vascular bundles, with a fairly abrupt transition from the dense congested peripheral vascular bundles via a sub-peripheral region to the center (their type B). The difference between these types is easily seen in sawn (chain-sawn!) palm trunks (e.g. figure 3 a) and they impart different biomechanical properties to the resulting mature stems. This distinction does not, of course, account for the different properties of palm stems of diverse habit, as for example either those with a rhizomatous or scandent habit.

The net developmental feature of type B stems is that primary cell maturation occurs over extended axial distances (youngest apically), but also radially as expressed most clearly in the maturation of the fibers of the bundle sheath (the cap) of vascular bundles (slowest in cells distant from the phloem). This sequence proceeds in the massive caps of the sheath of the outer bundles from sites close to the phloem in a radial direction outwards within individual bundles but only initiated among different bundles in an inward radial direction, as we have documented in figure 3 . The time of differentiation within different bundle types is not necessarily wholly consistent with this overview as independent fiber strands mature rapidly and the sheath of central vascular bundles does not follow a radial pattern at one level. From the axial point of view, differences along each bundle depend on the overall course contrasting central and peripheral portions as well as major versus minor bundles. The overall result, which has been extensively documented in a number of palms by Rich (1987), has mechanical consequences because the base of the stem increases in stiffness with age, an obvious adaptive feature in terms of conservation of biomass over the life span of a trunk. The contrast between the two types defined by Thomas $(2011,2013)$ has some phylogenetic relevance because type A stems seem more prevalent in the early diverging clades of Calamoideae and Coryphoideae, whereas type B is expressed most extensively in the Arecoideae to which the Bactridinae belong (Dransfield et al. 2008). Such stem developmental features thus seem to run in parallel with the changes in lamina anatomy extensively documented in Tomlinson et al. (2011). These examples illustrate the highly diversified potential of sustained primary growth in palm stems and the extensive work that is still needed before it is more fully understood. 
An obvious criticism of our approach is the virtual absence of any quantitative analysis. We give no time span to the successive events we describe because we had no knowledge of the age of our specimens. A thorough analysis would require a study of events as seen in thin sections throughout the length of a single trunk of known age. This has been done for very few species (Tomlinson 1990). The study of the palm stem has been described as the next great frontier of palm biology (Tomlinson et al. 2011). We can appreciate the extent of this task, but submit our results as a guide to further study. We concur with Eiserhardt et al. (2011) that the phylogenetic history of the Bactridinae continues to be a challenge, and suggest in future work that in addition to molecular markers structural evidence should also be sought, difficult though it may be to obtain.

Our example thus provides an explanation for the difficulty of identifying the systematic position of fossil palms. This situation obviously can be improved by future detailed study, which will have to accommodate the growth processes we have revealed.

\section{Acknowledgments}

Philip Barry Tomlinson acknowledges technical support over several years from Leslie Niyogi and Monika Mattmüller together with laboratory facilities at Fairchild Tropical Botanical Garden, Harvard Forest and the Kampong Garden of The National Tropical Botanical Garden.Tracy Monique Magellan acknowledges Larry Noblick, Antonieta Noblick, and Marta Magellan for helping to translate the abstract. Most stems used in this study were derived from early field collections of J.G. Wessels Boer and H.E. Moore. The living collections of Montgomery Botanical Center and Fairchild Tropical Botanic Garden were used in this study.

\section{Literature cited}

Baker, W.J., Savolainen, V., Asmussen-Lange, C.B., Chase, M.W., Dransfield, J., Forest, F., Harley, M.M., Uhl, N.W. \& Wilkinson, M. 2009. Complete genericlevel phylogenetic analyses of palms (Arecaceae) with comparisons of supertree and supermatrix approaches. Systematic Biology 58: 240-256.
De Nevers, G.A., Hunderson, A. \& Grayum, M.H. 1996. Mesoamerican Bactris (Palmae). Proceedings of the California Academy of Sciences 49: 171-210.

Dransfield, J., Uhl, N.W., Asmussen, C.B., Baker, W.J., Harley, M.M. \& Lewis, C.E. 2008. Genera Palmarum. Kew Publishing, Kew, UK.

Eisenhardt, W.L., Pintaud, J.B., Asmussen-Lange, C., Hahn, W.J., Bernal, R., Balslev, H. \& Borschenius, F. 2011. Phylogeny and divergence times of Bactridinae (Arecaceae, Palmae) based on plastid and nuclear sequences. Taxon 60: 485-498.

Henderson, A. 2000. Bactris (Palmae). Flora Neotropica Monograph 79. New York Botanical Garden Press, Bronx, New York.

Horn, J.W., Fisher, J.B., Tomlinson, P.B., Lewis, C.E. \& Laubengayer, K.M. 2009. Evolution of lamina anatomy in the palm family (Arecaceae). American Journal of Botany 96: 1462-1486.

Rich, P.M. 1987. Mechanical structure of the stem of arborescent palms. Botanical Gazette 148: 42-50.

Salzman, V. \& Judd, W. 1995. A revision of the Greater Antillean species of Bactris (Bactridinae; Arecaceae). Brittonia 47: 345-371.

Sanders, R. 1991. Cladistics of Bactris (Palmae): survey of characters and refutation of Burret's classification. Selbyana 12: 105-133.

Thomas, R. 2011. Anatomie compareé des Palmiers. Identification- assistée par ordinateur application en Paléobotanique et en Archéobotanique. Thèse docteur du Muséum d'Histoire naturelles. Paris. Available in http://lis-upmc.snv.jussieu.fr/Palm-ID/en/doc/ These_R_Thomas.pdf (access in 26-VI-2015).

Thomas, R. \& De Franceschi, D. 2013. Palm stem anatomy and computer-aided identification: the Coryphoideae (Arecaceae) American Journal of Botany 100: 289-313.

Tomlinson, P.B. 1961. Palmae. In: C.R. Metcalfe (ed.). Anatomy of Monocotyledons. v. 2. Oxford Clarendon Press, Oxford.

Tomlinson, P.B. 1990. The structural biology of palms. Oxford Clarendon Press, Oxford.

Tomlinson, P.B. \& Zimmermann, M.H. 2003. Stem vascular architecture in the climbing palm Desmoncus (Arecaceae-Arecoideae-Bactridinae. Botanical Journal of the Linnean Society 142: 243-254.

Tomlinson, P.B., Horn, J.W. \& Fisher, J.B. 2011. The anatomy of palms: Arecaceae-Palmae. Oxford: Oxford University Press.

Wessels Boer, J.G. 1965. The indigenous palms of Suriname. E.J. Brill, Leiden.

Zimmermann, M.H. 1983. Xylem structure and the ascent of sap. Heidelberg: Springer-Verlag. 